\title{
Om dejlige dage: Hiero- og teofore processioner i arkaisk religion og i Det Gamle Testamente
}

\author{
HANS J. LUNDAGER JENSEN
}

\begin{abstract}
ENGLISH ABSTRACT: This article, "On lovely days: hierophoric and theophoric processions in archaic religion and in the Old Testament", provides examples of processions and their significance in archaic Near Eastern religions and of the scholarly discussions on possible processions in the Yahweh-religion. The article also proposes that the prohibition against images in the Old Testament is rooted in an effort to immunize Jews against the attractions of processions.
\end{abstract}

DANSK RESUME: Artiklen her giver eksempler på processionernes betydning $i$ arkaiske, nærorientalske religioner og over forskningsdebatten om hvorvidt processioner også har været en del af Jahve-religionen $i$ Jerusalem. Afslutningsvis foreslås at det primære formål med det såkaldte 'billedforbud' $i$ GT har været at immunisere Jahve-dyrkere imod processionernes fascinationskraft.

KEYWORDS: processions; archaic religion; Egyptian religion; Mesopotamian religion; the ark; Durkheim; Rappaport; indexical and symbolic messages; prohibition of images.

I artiklen her vil jeg give et bidrag til belysning af processioner som religionsfænomenologisk og religionshistorisk tema ved at se på processioner i GT og i GT's nærorientalske kontekst. Gangen i artiklen vil være: (1) en begrebsafklarende indledning; (2) et generelt overblik over processioner og deres betydning for arkaisk religion; (3) eksempler på store og officielle processioner i egyptisk og mesopotamisk religion; (4) en redegørelse for ældre og nyere forskningsdiskussion om mulige lignende processioner i Jerusalem som en del af Jahve-religionen; og endelig (5) et kortfattet forslag til en forklaring på hvorfor processioner ikke blev en vigtig del af den Jahve-religion der udviklede sig til jødedom, kristendom og islam. 


\section{Begreber: 'procession', 'arkaisk religion'}

Med 'procession' vil jeg i denne artikel forstå et ritual, ${ }^{1}$ der er særligt ved at dets handling består i at deltagerne bevæger sig i en række fra ét sted til et andet ad en fastlagt rute. Jeg vil her alene beskæftige mig med en særlig form for procession, den 'hierofore', dvs. at processionens erklærede og for alle indlysende formål er at transportere en hellig genstand. ${ }^{2}$ Jeg antager at det har været denne processionstype der har været den vigtigste i antikke nærorientalske og mediterrane by- og statskulturers religiøse liv. Jeg antager også at processioner har været en helt afgørende del af det religiøse liv i arkaisk religion overhovedet. Med 'arkaisk religion' (Bellah 1964, 364366) forstås her en form for religion der typisk inkluderer individuelle, antropomorfe guddomme i et panteon (typisk eller altid et himmelsk), der sikrede den materielle verdens stabilitet og fastlagde sociale leveregler, med religiøst monumentalbyggeri, professionelt religiøst personale ('præsteskab'), daglige, rutineprægede ritualer, en markant udnttelse af visionelle repræsentationer (billeder, statuer m.v.) og en tæt forbindelse imellem 'stat' (typisk: kongedømme) og religiøse institutioner i snæver forstand (såsom templer). ${ }^{3}$ Overgangen fra en før-arkaisk til en arkaisk religionstype er naturligvis flydende; ${ }^{4}$ men som eksemplariske arkaiske religioner kan betragtes religionerne i tidlige by- og territorialstater, tidligst i Mesopotamien (omkring 3000 f.Kr.). ${ }^{5}$ Andre tidlige eksempler er Kina og Indien; men arkaiske religioner opstod også i Mellem- og Sydamerika (herunder maya- og azteker-kulturer samt inkaer) og i Afrika (Yoruba) (jf. Trigger 2003, passim).

Ved at være en begivenhed der kunne samle store befolkningsgrupper på samme sted har hierofore processioner været særlig egnede som rituel form for arkaisk religion. Transport af en hellig genstand forbi en befolkningsmængde løser det problem at en stationær genstand kun kan ses af de nærmeststående. Defilering af tilskuere omkring en stationær hellig genstand som ved circumambulation kan ses som en systematisk omvending af en hierofor procession. Ved circumambulation er det gudsdyrkerne der bevæger sig, mens den hellig genstand er stationær; ved processionen

1 Med 'ritual' vil jeg med Roy A. Rappaport forstå 'udførelsen (performance) af mere eller mindre invariante sekvenser af formaliserede handlinger og udtalelser, der ikke er fuldstændt fastlagt (encoded) af de udførende selv' (Rappaport 1999, 24; jf. Lundager Jensen 2003). Til denne definition vil jeg tilføje en Durkheimiansk præcisering: Ritualet udgør en undtagelse fra deltagernes daglige aktiviteter; det bringer deltagere sammen, som til daglig er adskilt rumligt; det forener deltagerne i et fælles forehavende, som adskiller sig fra individuelle og forskellige forehavender; og det skaber dermed en fælles 'bevidsthed' (dvs. opmærksomhed og hukommelse, og dermed viden), som er forskellig fra deltagernes individuelle bevidstheder. Et ritual er desuden beregnet på at fremkalde dannelse af en fælles oplevelse, dvs. et emotionelt indtryk knyttet til et sæt af forestillinger, som, hvis ritualet er vellykket, af deltagerne betragtes som noget positivt (Durkheim 1994 (1912) / 1995, passim).

2 Jf. "Indledning" i dette nummer af Religionsvidenskabeligt Tidsskrift.

3 Jeg vil betragte farao Akhnatons berømte sollysreligion som arkaisk, selv om den netop ikke var polyteistisk (Hornung 1995).

4 Jf. begrebet om 'høvdingedømmereligion' i Nygaard \& Murphys artikel i dette nummer af Religionsvidenskabeligt Tidsskrift.

5 Mesopotamisk religion var således helt grundlæggende en religionsform for byer, jf. Van De Mieroop 1999, 217. 
bliver den normalt stationære hellige genstand dynamisk: Den rækker aktivt ud til sine dyrkere, den gør sig synlig og kommer mennesker i møde. Processionen er en rituel udgave af åbenbaringen, en fremtrædelsesform der er særlig slående i religioner hvor det guddommelige er forbundet med himlen, det høje. Myto-teologisk er åbenbaringer her typisk vertikale: De kommer oppefra og ned. Den rituelle udgave er horisontal: Den kommer fra det indre til det ydre. Åbenbaringer foregår i et kosmologisk rum (himmel-jord); processioner foregår i et topologisk rum (tempel-profan verden).

\section{Templer, billeder, processioner i arkaisk religion}

I den Nære Orient (fra Mesopotamien i øst til Egypten i vest) var arkaisk religion grundlæggende tempelkult. ${ }^{6}$ Den daglige tempelkult blev varetaget af specialiserede og hierarkisk differentierede præsteskaber i bygningskomplekser isolerede fra lægfolket, og offerritualer for lægfolket var typisk beregnet på mindre grupper: familier, politiske sammenslutninger osv. Nærorientalsk religion har været en form for arkaisk religion med et større eller mindre antal individuelle og antropomorfe guddomme, indbyrdes forbundet igennem familierelationer, der havde etableret den virkelighed som mennesker levede i og et sæt af normer og regler efter hvilke menneskene skulle handle. I rumlig-spatial henseende var disse guddomme placeret dobbelt: Grundlæggende hørte de til steder uden for den umiddelbart erfarerede menneskelige virkelighed - ofte og typisk i himlen - men de kune også være til stede på jorden.

Den spatiale afstand imellem guddommene og menneskene (og andre jordiske væsener og ting) korrelerede med en ontologisk forskel. Guddomme på den ene side og mennesker (og dyr etc.) på den anden side var af så forskellig beskaffenhed at de ikke uden videre kunne opholde sig i hinandens nærhed og i hinandens sfærer. Mennesker risikerede at dø hvis de kom for tæt på en guddom, mens en guddom risikerede både at komme til at slå mennesker ihjel og at blive angrebet af den jordiske virkeligheds profanitet og urenhed. Det var altså nødvendigt for begge parter at holde en passende afstand. Så længe guderne var i deres himmel (hhv. i underverdenen, i havet etc.), var begge parter på den sikre side. Men da kommunikation imellem guddomme og mennesker i princippet også var ønsket af begge parter, var der en fælles interesse for guddomme og mennesker i at gøre et jordisk ophold for den ikke-jordiske guddom mulig. Templet var en løsning: et jordisk stykke 'anden-verden', en 'hetero-topos' ${ }^{7}$ med kontinuitet til den anden, himmelske verden, som det også kunne være et billede på. ${ }^{8}$

6 Der eksisterede andre former for religion på lavere sociale niveauer (navnlig på familieniveau), hvor de religiøse forestillinger, steder og praksisser har været anderledes, jf. Gerstenberger 2001 / 2002. Til de fundamentale fælles strukturer i nærorientalsk oldtidsreligion, jf. Smith 1952. - Til det følgende: jf. den korte sammenfatning i Assmann 2008, 14-17 om egyptiske forhold; disse gælder generelt i nærorientalsk, arkaisk religion og også bredere endnu.

7 'Heterotopi' angår 'anderledes steder', til forskel fra 'utopi' om steder der ikke findes (eller om meget gode, men urealistiske steder), jf. Foucault 1983; Sloterdijk 2009, 345; 2013, 222.

8 Jf. nedenfor om indeksikale tegn (kontinuitet) og ikoniske tegn (lighed). 
Et tempel var ikke en konstruktionsmæssig sui generis-kategori (som selve ordet 'tempel' kan give indtryk af), for det tilhørte kategorien 'hus'. Men som hus for en eller flere særlige beboere, nemlig guddomme, var det et særligt hus, dvs. det skulle være indrettet på en særlig måde med et særligt inventar, og hvor der kun var adgang for et særlig kvalificeret personale. Den basale modsætning imellem menneskenes dennesidige 'denne verden' og guddommenes hinsidige 'anden verden' var dermed blevet mere kompleks. Templet medierede imellem de to verdener ved at være et dennesidigt rum for en hinsidig aktør, altså et stykke anden verden indkapslet i en omgivende denne verden. For almindelige mennesker ville der ikke være adgang til gudernes sfære, hverken den ydre eller den indre anden verden. Almindelige mennesker kunne ikke betræde gudernes himmel, og de kunne ikke komme ind i de inderste rum $i$ templerne hvor gudestatuerne eller andre lignende hellige genstande var placeret. Den menneskelige virkeligheds sfære var dermed både omverden til et utilgængeligt centrum og selv centrum for en utilgængelig, hinsidig sfære. ${ }^{9}$

Altså var det rigtigt at guddomme normalt forblev i deres himmel eller i deres tempel. I himlen blev 'kulten' varetaget af himmelske væsener. På jorden, i templerne, var den normale kult forbeholdt præster, specialister i at omgås guddomme. Kulten foregik bag lukkede døre eller bag forhæng, der forhindrede eller besværliggjorde direkte adgang og syn for ikke-præster. Denne daglige, rutineprægede, men skjulte kult var imidlertid relevant for alle, præster som ikke-præster, for det var i kraft af guddommens tilstedeværelse at byen og dens territorium havde den guddommelige bevågenhed og dermed sikkerhed og trivsel - i det gammeltestamentlige vokabular: 'velsignelse' - som var den ultimative mening med arkaisk religion. Givetvis har de fleste mennesker accepteret et sådant ræsonnement. Det har været forståeligt at guddommene befandt sig på afstand af almindelige mennesker. Templets vægge og mure har ikke kun skærmet guddommene fra menneskene og givet dem den nødvendige ro og uforstyrrethed, men også skærmet menneskene fra guddommen. Arkaisk religion var funderet på overbevisningen om nødvendigheden af at opretholde afstande og grænser. ${ }^{10}$ Guddommene i deres boliger var både en ultimativ kilde og en overgribende baldakin over menneskenes daglige aktiviteter, deres arbejde, deres familieliv, deres reproduktion, kort sagt i deres 'økonomi'. ${ }^{11}$

9 GT er givetvis paradigmatisk her. Det understreges ofte at en umedieret konfrontation imellem en guddom eller et guddommeligt væsen, og et menneske risikerer at medføre menneskets død (Dom 13,22); det gælder også Moses (Ex 3,6; 33,22) ypperstepræsten (fx Lev 16,2). Deraf den udtalte modvilje hos mennesker imod direkte møder (fx Deut 5,25). Selv om patriarken Jakob i drømme ser en stige, der forbinder himmel og jord, og ser engle gå op og ned ad den, falder det ham ikke ind selv at ville bestige den (Gen 28,16f.).

10 Dette er værd at understrege, eftersom nærheden imellem anden-verdens-repræsentant og mennesker blev et vigtigt tema i aksiale religioner. På den ene side blev jorden til et fremmed sted for mennesker; på den anden side kunne mennesker forløses fra den fremmede verden ved et nært forhold til en guddom eller en repræsentant fra den anden verden. Sådanne basale aksiale strykturer er endnu tydelige i nadverliturgien i den danske folkekirke, hvor det hedder: 'styrk os i det indre menneske, at du må bo ved troen i vores hjerter'). Selv som metafor ville få eller ingen i GT's omverden have fundet et sådant udsagn meningsfuldt.

11 'Økonomi' i bred forstand, som 'husholdning': dvs. menneskenes udvekslinger med den materielle verden: Durkheim 1994 (1912), 497 / 1995, 392. 
Også selv om tempelkultens legitimitet formentlig har været bredt anerkendt i de nærorientalske bykulturer i oldtiden, vil rutiniseringen have indebåret et problem. Legitimiteten er her rent forståelsesmæssig: accept af en tankegang, et ræsonnement. Men mennesket er et dyr der ikke lever af tankegange alene; det lever også både af tegn, betydninger, meningsfuldhed og af lejlighedsvise samvær med andre mennesker. Ingen økonomi fungerer uden afbrydelser; intet privat og isoleret liv fungerer uden lejlighedsvise møder med andre mennesker, ingen dagligdag fungerer uden fester. Hvis guddommene lever i deres isolerede sfære inde i midten af eller oven over eller uden for menneskenes sfære, hvordan så forbinde de to? Selv om menneskene kan mødes med hinanden uden guddommen, hvordan kan de mødes på en sådan måde at den mest fundamentale grund til at de overhovedet eksisterer - og til at de har materielt og psykisk overskud til at afbryde arbejdet for periode og kan mødes uden at arbejde - formuleres på en tydelig måde, gøres nærværende, bliver mulig som oplevelse og erfaring?

Durkheim mente som bekendt at kulturer stabiliserer sig selv igennem effervescente forsamlinger omkring et fælles 'emblem', en genstand, et tegn, som betegnede det som den pågældende gruppe havde til fælles, idealet om dem selv. I den durkheimske vision er 'kultur' i sidste instans religion: fællesskab omkring et ideal, dvs. en forestilling som er transcendent i forhold til de konkrete kroppe som udgør en gruppe. Men i bykulturer med undertiden tusinder, eller mange tusinder, af mennesker, med deres 'byreligion', 12 er det ingen enkelt sag at forsamle mennesker omkring et fælles ideal, materialiseret $i$ et emblem. Templer er tydelige nok og egner sig fremragende (i bogstavelig forstand) som emblemer for store befolkningsgrupper. Men selv mægtige templer og himmelhøje ziqqurrater rutiniseres, og der har givetvis været borgere, der i deres daglige praksis kunne passere forbi templerne uden at lægge synderlig mærke til dem eller gøre sig dybere tanker om dem. For en levedygtig bykultur og byreligion har det været afgørende at genkalde dens religion og dens guder, at gøre dem nærværende for menneskenes bevidsthed, og det har været afgørende for en sådan befolkning at den fik revitaliseret dén fælles bevidsthed som overhovedet gjorde den til en overlevelsesdygtig enhed, en 'kultur'.

Processionen er svaret: Den afbryder rutinen uden for og inde i templet, og den bringer guddom og menneskelig gruppe tæt på hinanden, for en kort stund - den gør 'repræsentation til realpræsens' (Assmann 1996, 261). Det er meningen at guddommen skal vise sig frem for menneskene; og det er meningen at menneskene skal se guddommen - eller i det mindste ane et tættere nærvær end normalt. Processionen skrider frem igennem byens gader; altså er det nødvendigt at de normale aktiviteter i disse gader standser eller indskrænkes. Ingen procession uden en form for politimyndighed der har magt til at bestemme hvad der må foregå i gaderne, og som kan holde tilskuerne og deltagerne inde i bestemte rammer. Ingen arkaisk religion uden forståelse og samarbejde imellem religion og stat.

12 van der Toorn 1991, 336; Lundager Jensen 2016b; 'byreligion' er her grundlæggende identisk med 'arkaisk religion'. 
En given procession kan have flere betydninger, flere meddelelser. Disse hører hovedsageligt hjemme i de myto-teologiske koder som kan væves ind i processionen, og som registreres mere eller mindre klart af deltagerne, men som primært hører til processionens professionelle personale, præsternes, domæne. Det er dem der vil kunne give (evt. alternative eller modstridende) forklaringer på og fortolkninger af, hvad meningen med en given procession er. I GT kan det have været at Jahve har besejret kaosmagterne og indtaget sin trone, og/eller at han har accepteret sin konge og lovet ham endnu et succesfuldt år, og/eller at regnen snart vil komme, og/eller at den politiske, sociale og religiøse orden i denne by er den helt rigtige og for enhver pris skal bevares. Men processionen har en 'basismeddelelse' der gives under alle omstændigheder, uanset de myto-teologiske kodninger. ${ }^{13}$ Den er simpel, men uundværlig: at denne guddom overhovedet findes og at den befinder sig i ens rumlige nærhed. Ingen religion uden lejlighedsvise genkaldelser af dens vigtigste budskaber. En arkaisk religion har som alle religioner og alle ikke-materielle betydningsdannelser, kort sagt alle 'kulturer', skullet skaffe sig plads i en gruppe menneskers bevidsthed. Men i en arkaisk religion, hvor den blotte bevidsthed om eksistensen og relevans af religion i bred og abstrakt kan forudsættes at have været til stede stort set overalt, har det været mere umiddelbart relevant at fremhæve hoilke bestemte guddomme der har været relevante for en konkret gruppe.

Religion i hvilken som helst form ${ }^{14}$ er ikke kun et spørgsmål om kvalitet, men også om kvantitet. Den kvalitative dimension er deri, hvor religioner adskiller sig fra hinanden: denne eller hin guddom, denne eller hin kosmologi, ethos etc. Den kvantitative dimension er fælles for alle religioner, for den angår graden af den mentale intensitet hvormed den er til stede i menneskers bevidsthed. Et menneske er ikke kun dyrker af denne eller hin guddom, men også en mere eller mindre opmærksom, begejstret og overbevist dyrker. Som del af menneskers liv kan en religion normalt ikke være en konstant faktor ${ }^{15}$ for den religiøse bevidsthed vil til stadighed være udsat for alternativer, dvs. andre ting og forhold i deres verden som mennesker må tage hensyn til, som melder sig i deres bevidsthed og indfanger deres opmærksomhed. En religiøs bevidsthed vil altid oscillere imellem uopmærksomhed og engagement, indifferens og begejstring, glemsel og hukommelse. Det mest elementære middel til fastholdelse af de forestillinger og de emotioner, hvis indhold definerer en bestemt

13 Det følgende er en konkret udnyttelse af Roy A. Rappaports sondring imellem ritualets 'overfladiske' eller 'formale' og 'dybe' eller 'substantielle' aspekter. De 'dybe' er de myto-teologiske betydninger; de 'overfladiske' er de effekter et ritual har i og med og alene ved at blive udført, uanset mytologiske begrundelser og teologiske betydningslag (Rappaport 1979; 1999, 30-31).

14 Og beslægtede fænomener: politik, kultur, selv kærlighedsforhold.

15 'Aksiale' religioner er ganske vist udtryk for vilje til at holde den religiøse bevidsthed på et konstant højt niveau: "men giv at al vor længsel må / til dig, til dig alene stå” (Brorson). Informationsteknologi kan her hjælpe: "Lykkelig den, som ... grunder [læser] på hans lov dag og nat” (S1 1; med 'lov', hebraisk torah, menes her formentlig 'belæring'). 
religion, er ting - genstande som har fået tilskrevet den særlige betydning at repræsentere eller signalere denne religion og som derfor kan være instrumentel med hensyn til genkaldelse af forestillingerne og emotionerne. ${ }^{16}$

Her kan det være nyttigt med en kort omvej omkring et lille stykke religionssemiotik, inspireret af antropologen Roy A. Rappaport. ${ }^{17}$ Gudestatuer og andre hellige genstand adskiller sig indbyrdes ved deres form; de kan opdeles i ikoniske og anikoniske genstande; og de kan være antropomorfe, teoriomorfe (dyre-lignende) etc. Men uanset hvad, er de frem for alt ting der signalerer. Dermed tilhører de klassen af indeksikale tegn, dvs. tegn der har deres betydning igennem den association de vækker til det de betegner. Indeksikale tegn er relativt lette at aflæse, for de kræver et ringe eller i nogle tilfælde intet kendskab til en bestemt kode. Også kropslige signaler: gestus og ansigtsudtryk, er indeksikale tegn.

Indeksikale tegn adskiller sig fundamentalt fra sproglige tegn (talte såvel som skrevne, der her kan kaldes 'symbolske'); begge typer har stærke og mindre stærke sider. I semantisk henseende, dvs. hvad angår indholdet i deres udsagn, kan symbolske tegn være uendeligt præcise: "With symbols discourse can escape from the here and now to dwell upon the past, future, distant, hypothetical, and imaginary" (Rappaport 1979, 180); indeksikale tegn derimod kan kun betegne faktisk nærvær. Med ord kan man sige at 'jeg vil måske være din ven i morgen'; med indeksikale tegn såsom et smil eller en åben håndflade kan man kun sige (ca.) 'jeg er din ven her og $n u^{\prime}$. En ark eller en gudestatue kan kun sige (ca.) 'her er en guddom'. Til gengæld kan indeksikale tegn sige det lidet de siger, langt mere tydeligt og effektivt. Med tale og skrift kan man kommunikere i det uendelige om Jahve, hvordan han er og hvad han hedder, hvad han har gjort og kan tænkes at ville gøre, osv. Men jo mere der tales og skrives, jo mindre vægt har de enkelte ord og sætninger, jo lettere sætter rutinisering og uopmærksomhed ind. Med hans ark, hans hellige kasse, etableres hans virkelighed her og nu på en måde som har alle muligheder for at gøre indtryk. Indeksikale tegn er materielle og tunge: Arken skal transporteres på en vogn eller bæres med stænger på skuldrene af voksne mænd; templet og ziqqurraten er omtrent uflyttelige. Symbolske tegn er meget lette; de vejer ikke mere end en lydbølge eller, i vore dage, blæk på papir; de kommer og går, ind og ud af bevidstheden.

Arkaisk religion kommunikerer med indeksikale tegn: med bygninger, statuer, kasser, klædninger, musik, gestikulationer, dufte, farver og forme. De kan sige meget - det gør de i myter, hymner, bønner; og sproglige tegn er uden tvivl også nødvendige for at gøre religionen plausibel og relevant. Men de behøver formentlig ikke sproglig kommunikation i noget større omfang for at få deres fundamentale budskab igennem: At denne bestemte guddom er her, at han eller hun er til stede i den menneskelige verden, men egentlig kommer et andet sted fra, at det er her kilden er til det daglige mirakel, som verdens opretholdelse er, og det er her, der kan ske små og lokale, men

16 Jf. Durkheim 1994 (1912), 330 / 1995, 232-233. Det var ikke mindst denne kvantitative dimension ved religion som gjorde det meningsfuldt for Durkheim at aflede al kultur af en oprindelig 'religion'.

17 Rappaports semiotik er udviklet på grundlag af elementer i den amerikanske filosof Charles Sanders Pierces' semiotik, jf. Rappaport 1979, 180-183; 1999, 54-68. 
så meget mere relevante og interessante mirakler såsom individuelle helbredelser, velsignelser, beskyttelse.

Det er normalt i forskningen at understrege den politiske funktion, officielle processioner af denne type tjente, ved siden af eller vævet sammen med myto-teologiske budskaber om gudernes eksistens, identitet og store gerninger ved verdens skabelse. Store statsligt-officielle processioner blev ledet af konger, og de tjente i høj grad til legitimation af regenter, deres magtapparat og hele den socio-politiske orden. I arkaiske religioners store, officielle processioner er det ikke kun guderne befolkningerne ser, men også kongerne. På den arkaiske religionstypes præmisser er dette indlysende, for både i forestillingsverdenen og i den socio-økonomiske verden var der en gensidigt støttende og legitimerende relation imellem stat og religion - rimeligt nok da arkaisk religion per definition er en religionstype der er mulig i og relevant for en stat og altså for mennesker som foretrækker at bo i en by. Ingen templer uden en omgivende stat som garant og beskyttelse. Det gør det imidlertid også en anelse problematisk at tale om politisk legitimering som en abstrakt-generel størrelse. Formentlig har kongedømmet som sådan, som princip, ikke haft brug for nogen legitimering for det store flertal af bymennesker i arkaiske kulturer. Kongedømmet som institution har været en del af den generelle kosmologiske orden og lige så lidt oplagt at kritisere som solens eller årstidernes gang. Derimod kan der meget vel have været brug for at legitimere bestemte personers ret til kongedømmet. Men ved at lede en procession der som et ritual er i høj grad fastlagt på forhånd og altså udtryk for en orden som kongen ikke selv har bestemt, signalerer kongen (indeksikalt) at han gerne vil fremstå som en legitim, retmæssig og retfærdig magtudøver. Naturligvis er og var idealer ikke det samme som virkelighed. Men signaler er større end hykleri, 'ideologi' større end konkret magt. Offentlig accept er vigtigere end individuel overbevisning (Rappaport 1999, 119-124). Processionen fremviser en ideel orden hvis eksistens magten er nødt til at anerkende også for sit eget vedkommende.

Selv om der således utvivlsomt har været hvad man mere nøgternt end 'legitimering' kan forstå som en 'politisk kode' i arkaiske processioner, vil det formentlig være misvisende at se dette som det egentlige, det centrale ved processionerne. Man kan dårligt forestille sig store menneskemængder samle sig for med begejstring at lade sig udsætte for politisk legitimering. Også selv om man vil gå så langt som til at forstå forholdet imellem procession og politisk magt som forholdet imellem en uvidendenaiv masse og en kynisk manipulerende elite af konger og præster, er det umuligt ad denne vej at forstå processionernes attraktion. Lige som processioner kan betyde meget forskelligt, kan de givevis også bruges til meget forskelligt. Men brugen er sekundær og forklarer ikke fænomenet i sig selv. Det grundlæggende attraktive ved processioner må have ligget i det rituelle i sig selv: pragten, det eksotiske, det andenverdens-fascinerende, bruddet med dagliglivets rutiner (herunder synkroniseringen af kroppe i bevægelse), festen og glæden - alt det der indfanger opmærksomheden og som gør processionen interessant. Det må have været alle de indeksikale tegn som processionen samler sammen og kombinerer, som har gjort at mennesker har valgt ikke at blive hjemme og passe deres daglige rutiner, men har fundet det mere relevant at stille sig op og vente på at processionen skal passere forbi. 
I øvrigt har de store processionsfester i arkaiske kulturer i oldtiden haft en tiltrækningskraft på flere end den lokale befolkning. De har været en anledning til at foretage en rejse til den by hvor festen foregik, evt. også hilse på derboende relaterede, og man har haft noget at fortælle om når man kom hjem. Kuriøst nok kan det nutidige begreb om 'teori' afledes fra udsendtes rapporteringer om processionsfester i andre byer. ${ }^{18}$

Billedudsmykninger og byplanlægning viser processionernes enorme betydning. Arkaiske byer har været beregnet til processioner. I Babylon gik den største og mest pragfulde (og dermed den mest resursekrævende) gade fra Marduk-templet til Ishtar-porten. ${ }^{19}$ I det egyptiske Theben var templerne i det store Karnak-kompleks-kompleks via processionsgader forbundet med hinanden, med kajer ved Nilens bred og med det mindre Luxor-tempel (Kemp 1989, 205). Hvor vigtige processioner har været for både templerne og den almindelige befolkning, fremgår af de talrige relieffer der udsmykker egyptiske templer med scener fra processioner, ligesom Parthenon-frisen fra hovedtemplet i Athen gengiver deltagere i processionen ved den store panathenæer-fest. ${ }^{20}$

Processioner var af alle grunde oplagte som billedmotiver, ikke mindst fordi processioner er ordninger af mangfoldigheder. Arkaiske kulturer forudsatte en evne til at håndtere mængder og forskelligheder, ikke kun praktisk-politisk og socialt - såsom forskellige etniske og sociale menneskegrupper - men også mentalt. Overalt i arkaiske kulturer findes skriftlige og billedelige fremstillinger af mange størrelser: guder, etniske typer, dyr, planter, byer. Gennemgående kognitive greb var kategorisering, placering i rækkefølge og hierarkisering. Processionen er et produkt af evnen til at tænke mængde og sammenhæng, omsat som en fremskridende række. Her har alt sin rette plads: Omkring et centrum - gudestatue, konge, hellig genstand - placeres andre typer af deltagere: andre guder, som statuer eller som ikke-ikoniske tegn, grupper af mennesker, evt. dyr, med afvigende grad af betydning. Formentlig har det været muligt for lægfolket at slutte sig til processionen, bagerst, som en slags markering af at ingen ordener kan tildele alle elementer en lige fast placering i et velordnet system. I så tilfælde vil processionens afslutning også synliggøre overgangen fra ordenens centrum til en grænseperiferi, hinsides hvilken der kun vil findes uklar ubestemmelighed. ${ }^{21}$ Men pragten og skønheden i processionens centrum giver også meddelelse

18 Jf. Bellah 2011, 577, med henvisning til Andrea Nightingale, Spectacles of Truth in Classical Greek Philosophy (2004): det græske begreb 'theoria' har betegnet en rapport fra en udsendt theoros, som "was sent as an official representative of his city to view a religious festival in another city and then return

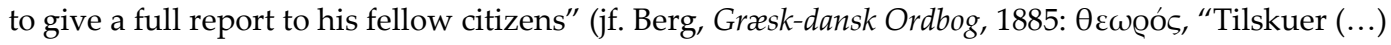
en offentlig Afsending, der paa sin Stats Vegne bivaanede en Fest, raadspurgte et Orakel, bragte et Offer"). Med 'religious festival' kan man givetvis forstå navnlig offentlige processioner.

19 Et pragtbyggeri der som bekendt nu er i Pergamon-museet i Berlin.

20 Price 1999, 30-34; Zaidman og Pantel 1992, 105-107; jf. Anders Klostergaard Petersens bidrag til dette nummer af Religionsvidenskabeligt Tidsskrift.

21 Pladsen her tillader ikke udfoldelse af dette 'ontologiske' perspektiv; det drejer sig om den særligt 'analogistiske' ontologi, som antropologen Philippe Descola har defineret som alternativ til andre ontologier, navnlig animisme, der er typisk for mange jægersamfund, og naturalisme, der er dominerende i moderne samfund. Til analogistiske billeder, jf. Descola 2010; som foreløbig dansk introduktion: Lundager Jensen 2016a. 
om at hvis kilden til det hele er skøn og god, så er helheden det også, om end i aftagende grader. ${ }^{22}$

\section{Nærorientalske processioner: Egypten og Mesopotamien}

Processioner har været almindelige i de nærorientalske arkaiske religioner, som de er det endnu i bl.a. religioner der har bevaret eller revitaliseret fundamentale arkaiske træk såsom kinesiske og indiske religioner og romersk katolicisme. ${ }^{23}$ De er også relativt velbelyste når det kommer til de store oldtidskulturer, mesopotamisk og egyptisk; det er ikke vanskeligt at finde redegørelser tilgængelige for ikke-specialister.

\subsection{Egypten: opet- og dal-festerne}

Processioner var hyppige i og helt centrale for egyptisk religion. ${ }^{24}$ Berømte som eksempler er to store processionsfester i det egyptiske Theben, det religiøse centrum i den sydlige del af landet. Fra hovedguddommen Amuns tempel i Karnak udgik store processioner under kongens ledelse i forbindelse med to store årlige fester, hhv. opetfesten med en procession der gik til det mindre, mere sydligt beliggende Luxor-tempel, og dal-festen, hvor en procession med samme udgangspunkt i Karnak gik til 'dødetemplerne' ${ }^{25}$ på vestbredden af Nilen. Opet-festen fandt sted i august-september, efter den årlige stigning i Nilens vandstand, mens dal-festen fandt sted efter kornhøsten i varmeperioden forud for den vandstandsstigningen (dvs. i forår-tidlig sommer efter vor tidsregning). I begge tilfælde blev særlige processionsstatuer af Amun, Mut og Khonsu, der var anbragt på mindre både, båret ned til Nilen, hvor de blev lastet på større både der blev trukket hhv. op ad og tværs over floden, hvorfra de igen blev båret videre til deres bestemmelsessted. ${ }^{26}$ Ruterne har indeholdt stationer undervejs hvor processionen er standset op og præster har reciteret bønner og lovprisninger. Opet-festen varede flere uger (mellem 11 og 27 dage; dal-festen to dage). Ved opetfesten indgik der militære og civile deltagere, musikere og nubiske dansere. ${ }^{27}$

22 Når det i den første skabelsesberetning i Gen 1 som et omkvæd hedder at verden er 'god', hebraisk tôob, menes der både 'god' i betydningen 'velfungerende, velindrettet, i orden' og i betydningen 'smuk'.

23 Jf. min indledning til dette nummer af Religionsvidenskabeligt Tidsskrift og til artiklerne af Mikael Aktor og Marianne Qvortrup Fibiger. En nyttig komparation imellem nutidig kinesisk og romersk-katolsk-kristne processioner i Overmyer 1997.

24 Bonnet 1952, 610. If. Jan Assmann $(1991,106)$ var de store egyptiske årsfester simpelthen processionsfester. Det fremgår ikke kun af billeder og indskrifter, men også og ikke mindst af selve tempelarkitekturen: ligeså store resurser blev brugt på anlæggelse af processionsveje og stationer undervejs som på templerne selv, jf. Kemp 1989, 205.

25 Egentlig templer for Ammun: Kemp 1989, 209-211.

26 Processionsvejen ved opet-festen har varieret historisk. Under den kvindelige farao Hatshepsut (ca. 1479-1458 f.Kr.) blev statuerne båret fra Karnak til Luxor ad en særlig processionsvej. Senere blev de sejlet begge veje.

27 “Opetfest", Lexikon der Ägyptologie, Bd. 4, 1982. 
Gudestatuerne, der blev brugt i processionerne, var mindre og forskellige fra de stationære statuer i templerne. De var anbragt i små baldakiner på deres processionsbåde, med forhæng trukket for, så de har næppe været synlige for tilskuerne. Dermed fik denne procession muligvis mere karakter af en hierofor end en egentlig teofor procession, hvor den indeksikale dimension var vigtigere end den ikoniske. Det afgørende var i så fald ikke statuernes antropomorfe udseende, men deres materielle tilstedeværelse, deres karakter af hellig 'ting' i sig selv, mere end billede af noget helligt. Vigtigere end viden om hvad der præcis var inde i de små transportable kapeller, må have været fornemmelsen af at der var noget meget vigtigt derinde. ${ }^{28}$

De myto-teologiske temaer i de to fester var hhv. en revitalisering af de levende og et møde mellem de levende og de døde. I opet-festen fik Amun-Re fra Karnak, dvs. Amun som kosmokrator, og hans menneskelige konge nyt liv (og legitimitet) i og med opholdet i Luxor-templet, hvis residerende guddom var en særlig form for Amun: Amun-Min, en mere tydelig frugtbarhedsformidler; opholdet synes også at have inkluderet en form for hieros gamos imellem Amun og Mut (Darnell 2010, 5-6). Dalfesten tematiserede fællesskabet imellem levende og døde. Vestbredden var begravelsessted (jf. 'kongernes dal' lidt længere mod vest) både for konger, hvoraf nogle havde store Amun-templer der, og for den brede befolkning. Dal-festen er blevet sammenlignet med andre årlige fester hvor døde og levende holder gilde sammen (Schott $1952,91)$. Som en folkelig begivenhed med musik, dans og rigelige mængder af alkohol involverede den særligt gudinden Hathor, 'drukkenskabens herskerinde' (ibid., 76-78). Af mange gode grunde var en processionsdag 'en dejlig dag' (hrw nfr) (Assmann 1991, 105).

I begge processioner var den præsteligt-professionelle transport af gudebillederne omgivet af et betragtende og deltagende lægfolk. Processionen var per definition en fridag for en stor befolkningsmængde, en festdag med guddommenes besøg i den menneskelige virkelighed som centrum, men med fest, spisning og drik, begejstring og givetvis afstressning, altså med alle de brud på daglige rutiner som var med til at gøre det til 'en dejlig dag'. Men processionerne var mere end det. Ikke mindst kunne tilskuere tage varsler, orakler, af statuernes bevægelser - $\mathrm{fx}$ om statuerne pludselig blev uventet tunge, standsede op, svajede til den ene eller den anden side. Her var en kilde til besvarelse af spørgsmål om helbredelse fra sygdom, om hvem der var en tyv, om man ville stige i graderne eller få en særlig kornration osv..$^{29}$ Processionen udgjorde dermed også en mulighed for mennesker til direkte at forbinde deres egne problemfyldte liv med de ophøjede og normalt så fjerne guder; officielt religion og

28 Af dømme efter en religionsfænomenologisk konstans: det helliges 'kontaminerende' væsen; jf. Durkheim 1994 (1912), 455-457 / 1995, 322-324.

29 Jf. fx Sauneron 1998, 113-115; Roeder 1960, 241-251. - Der består en åbenlys kontinuitet fra arkaiske gudebillede-processioner til kristne relikvie-processioner i middelalderen, hvor de afdøde helgener på lignende måde kunne meddele sig til deres tilbedere (Bartlett 2013, 285). - If. legenden om overførelsen af Sankt Stefanus' relikvier til Rom signalerede helgenen sin utilfredshed med den først udtænkte begravelsesplads ved at forhindre at bærerne kunne komme videre, indtil det rette sted var blevet bestemt (Legenda aurea: "De inventione sancti Stephani protomartiris"; jf. Jacque de Voragine 1998, 397-398). 
'personlig fromhed' blev forbundet i den ventende tilskuers møde med guddommen. ${ }^{30} \mathrm{I}$ kraft af processionen kunne det officielle og fælles integreres med det personlige og private, det indlysende fornøjelige med det problematiske og angstfyldte.

\subsection{Mesopotamien: akitu-festen}

Processionsfester i Mesopotamien har grundlæggende været af samme type som de egyptiske ${ }^{31}$ med udgangspunkt i templer, hiero- eller teofore processioner, folkelige festdage der har forenet elite og almindelige mennesker, konge og undersåtter, præster og lægfolk. Processioner har været et hyppigt genkommende fænomen. En by som Babylon havde ikke kun det store, centrale Marduk-tempel (Esagila) med dens 90 meter høje ziqqurrat (Etemanki), men også lokale templer for forskellige guddomme fordelt i de forskellige kvarterer i byen, formentlig analogt til placering af sognekirker i en større middelalderby og endnu i vore dage. Hver af disse havde deres lokale festdage og deres egne processioner. ${ }^{32}$ Den mest nærliggende mesopotamiske parallel til den egyptiske opet-fest er den berømte akitu-fest, ${ }^{33}$ en fest hvis oprindelse går tilbage til sumeriske byer i det 3. årt. f.Kr., muligvis Ur, og som kan spores langt op i det 1. årt. e.Kr. i fester i Syrien (Geller 1997; Midbead 2004, 33-38).

Grundelementet i akitu-festerne var en offentlig procession med gudebilleder fra hovedtemplet igennem en bys gader og uden for bymuren, et ophold i et særligt akitu-hus dér og tilbagekomst og geninstallering af guderne i hovedtemplet. Akitufesten blev afholdt én eller to gange om året. ${ }^{34}$ Forestillingsindholdet har varieret, som rimeligt er over så stor en periode og så stor en geografisk spredning. Oprindeligt har den nok været en fest i anledning af afslutningen af kornhøsten om foråret. Men den har naturligvis haft både et myto-teologisk og et politisk indhold, for så vidt som både byens, dens guders og dens herskere er blevet bekræftet og evt. revitaliseret. I byen Babylon i 1. årt. f.Kr. var det en stor regional begivenhed, der fandt sted i årets første måned, nisan (ca. marts-april), og som varede i elleve dage. Gudestatuer fra andre byer, navnlig statuen af den betydningsfulde guddom Nabu fra byen Borsippa, blev sejlet til Babylon og anbragt i det centrale Marduk-tempel, hvorefter de førtes i en offentlig procession ${ }^{35}$ af den særlige processionsgade til Ishtar-porten og derfra ned

30 Jf. Assmann 1996, 261; Sauneron 1998, 113-115; Stadler 2008, 7. Jf. til mesopotamisk religion: Schaudig 2008.

31 Selv om jeg endnu ikke har fundet specialist-publikationer fra hhv. egyptologisk og assyriologisk hold, som eksplicit sammenligner opet- og akitu-festerne (eller panathenæer-festen, for den sags skyld), er de for mig at se indlysende variationer over et fælles skema. Til både-processioner generelt, inkl. opet- og akitu-festerne, dog jf. Canney 1938.

32 Jf. festkalenderen for Babylon og Uruk i seleukidisk tid: Hrusha 2015, 96.

33 Teksterne er samlet i Pongratz-Leisten 1994; basis for en orientering i den aktuelle forskningsstand: van der Toorn 1991; Bidmead 2004; Zgoll 2006.

34 I de sumeriske byer i det 3. årt. f.Kr. blev festen afholdt to gange årligt, med en efterårsfest et halvt år efter forårsfesten til fejring af så-sæsonens begyndelse (Cohen 1993, 150); tilsvarende for Uruk i første årt. f.Kr. (van der Toorn 1991, 332, n. 4). Så vidt jeg kan se af faglitteraturen, er det mere uklart om der var én eller to årlige akitu-fester i byen Babylon.

35 Forskningslitteraturen er ikke speciel informativ om hvordan transporten af statuerne ud til bådene foregik: båret på skuldrene, trukket på vogne? Es 46,1 kan være en indikator: "Bel [dvs. Marduk] går i knæ, Nebo [Nabu] synker sammen, gudebillederne læsses på lastdyr og okser" (jf. Schaudig 2008, 
på både, hvor de blev sejlet til et tempel uden for byen, akitu-huset. ${ }^{36}$ Her afholdtes bl.a. en stor fest med rigelig forplejning for alle (Hrusha 2015, 105). På månedens 11. dag blev guderne ført i procession tilbage til Marduk-templet, hvorefter de andre byers guder vendte hjem til deres egne templer. I og med denne samling af guder fra andre byer blev Babylons og Marduks førerstilling demonstreret og stadfæstet. Det samme blev den babyloniske konge, der førte an i processionen. Kongens rolle var afgørende for gennemførelsen af akitu-festen: Den sidste babyloniske konge før den persiske magtovertagelse af hele Mesopotamien (i 539 f.Kr., under kong Kyros), Nabonid, mistede sin legitimitet i Marduk-præsteskabets øjne, da han opholdt sig i den nordarabiske oaseby Tema i ti år, og akitu-festen derfor ikke kunne gennemføres (jf. Ravn 1934, 213-216).

Der er bevaret udførlige tekster fra Babylon fra seleukidisk tid angående ritualer på 2. til 5. nisan. ${ }^{37}$ Disse tekster rummer ordrige bønner til Marduk og til hans hustru Sarpanitu, en procedure for renselse af templet (med en særlig spektakulær renselse af Nabu-kapellet forud for Nabu-statuens ankomst ${ }^{38}$ ), en oplæsning af skabelsesmyten Enuma elish foran Marduk-statuen i templets cella og et ritual hvor kongen først aftages sine herskersymboler, derpå fremsiger en erklæring om ikke at have skadet Babylon og dens indbyggere, så får sine værdighedstegn tilbagegivet og til sidst af ypperstepræsten får et slag på hovedet; hvis konges tårer flyder, er det et gunstigt tegn. De indledende dage er specialiserede, præstelige ritualer, der kun involverer tempelpersonalet og kongen, og de er forberedelser til den egentlige festlige del. Denne består af to processioner. I den første, på den 8. nisan ${ }^{39}$, føres gudestatuerne ud af byen, og på den 11. nisan føres de tilbage igen. Den første procession, ud af byen, kan være foregået om aftenen (Zgoll 2006, 32). Det giver god mening at antage at den vigtigste af de to processioner, den 'egentlige' og store fest, har været tilbagekomsten, hvor Marduk og hans gudefølge er kommet ind igennem Ishtarporten, taget sin by i besiddelse igen og er blevet installeret i sit tempel (Cohen 1993, 404-405).

I forskningslitteraturen er der en vis tendens til at forklare akitu-festen ud fra de myto-teologiske forestillinger der eks- eller implicit kan læses ud af teksterne. Eksempelvis har Manfred Hutter (1996, 76-80) opregnet seks dominerende temaer: (1) frugtbarhed: Festen afholdtes efter byghøsten; (2) teologisk-politisk orden: Marduks herredømme over de andre guder blev demonstreret i denne 'nationalfest' for (byen) Babylon; (3) mytologi: Festen udspillede dramatiske fremstillinger af enkelte episoder fra Enuma elish; (4) kalender: Festen markerede det mesopotamiske nytår; (5) socialtpolitisk orden: Festen fremstillede rituelt kongens indsættelse som Marduks ypperstepræst; (6) lokal teologi: Festen gav en særlig prominent plads til guddommen

557; Berger 2008, 449). Men denne (satiriske) passage er også blevet forstået som henvisninger til fjendtlig bortførelse af statuer (Hays 2014, 282-283) eller til flugt (North 1964, 163-164). Jeg vender tilbage til passagen nedenfor.

36 Nogle få hundrede meter nord for Ishtar-porten, if. Bidmead 2004, 115-116.

37 Dansk oversættelse i Koch \& Westenholz 2015, 185-193.

38 Dette særlige ritual involverede udover renselse med vand, røgelse og olie også blod fra en vædder, at vædder-kadaveret derefter blev kastet i floden, og at den rensende præst og slagteren herefter var udelukket fra byen indtil akitu-festen er forbi.

39 Eller den 9., if. Bidmead 2004, 93-95. 
Nabu og markerede dermed dennes opstigning i gudehierarkiet. (Ingen af disse punkter inkluderer processionerne.)

Hutters punkt (3) anslår en solid tradition i forskningen for at antage et tæet forhold imellem akitu-festen og Enuma elish og dermed en myto-kosmologisk tematik. If. denne betragtning skal festen have genaktiveret kaos-kæmperen og verdensskaberen Marduk og hans grundlæggelse af Babylon tilbage i tidens begyndelse. Argumentet herfor er det indlysende forhold at både Enuma elish og akitufesten har guddommen Marduk som hovedfigur. Desuden associeres der undervejs i festen flere gange til Marduks sejr over ur-monstret Tiamat (Bidmead 2004, 91-93. 116). Tilmed blev Enuma elish som sagt læst op som del af de indledende ritualer forud for processionerne.

På den anden side foregik oplæsningen så fjernt fra offentlig deltagelse som muligt, så en mulig forbindelse imellem myten og ritualet har ikke af den grund nødvendigvis stået klart for det store flertal af tilskuere til processionerne. Forholdet mellem akitu-ritualet og Enuma elish-myten er i den nyere forskning særlig understreget af Anette Zgoll, der ser mytens struktur som en underliggende tekst for akitu-festen, der altså dermed repræsenterer og gennemspiller en mytologsk formuleret orden. ${ }^{40}$ Samtidig har man i forskningen også fremhævet den politiske dimension, dvs. at festens overordnede tema og raison d'être skal have været byen Babylons hegemoni og evt. kongens legitimitet. ${ }^{41}$

Akitu-festen har givetvis i varierende omfang til forskellige tider kombineret bl.a. økonomi, myte, kosmologi, Marduk-teologi, Babylon-centrisme og konge-ideologi. En af dens styrker har netop været muligheden for at sammenfatte eller sammenflette alle disse betydningsfelter på samme tid i én dramatisk udførelse og fremvisning. Det er alene af den grund rimeligt at atage at en procession som akitu-festen kan have været en arkaisk kulturs primære religiøse begivenhed. Men disse betydningslag har ikke nødvendigvis stået specielt klart for den store befolkning. De har tilhørt en specialviden, primært relevant for et traditions- og skriftkompetent præsteskab. ${ }^{42}$

40 Et af Zgolls argumenter for denne version af en 'myth-and-ritual'-analyse er de to gudeforsamlinger med 'skæbne-bestemmelser', der indgår i akitu-festen på hhv. den 8. dag og den 11. dag, hhv. før og efter processionerne. De svarer til to gudeforsamlinger i Enuma elish, hhv. før Marduks kamp med Tiamat og efter skabelsen af menneskene og bygningen af Babylon; den første indsætter Marduk som aktiv kæmper, den anden som permanent hersker (Zgoll 2006, 40. 65-66. 71). Den strukturelle overensstemmelse kan nok forklares på andre måder, fx ved at Enuma elish følger akitu-festen, eller ved at forholdet mellem den (unge) kriger og den (modne) hersker er en genkommende konstellation i mange kulturer (i GT således i forholdet mellem krigeren David og administratoren Salomo, jf. Lundager Jensen 2000, 358-359).

41 Se fx Koch \& Westenholz 2015, 194-195. Sommer (2000) har forsvaret en myto-kosmologisk forståelse.

42 Enuma elish er i øvrigt en udpræget lærd tekst, givetvis et produkt af præsteligt-skriftkyndiges særlige kompetencer og interesser (Oppenheim \& Reiner 1977, 264-266). - De skriftlige kilder er i dobbelt forstand attraktive for nutidens forskere: Udover deres faktiske informative værdi ligger det interessevækkende ved dem også i hele deres sprogligt-intellektuelle tilstand, hvor betydningslag differentieres, systematiseres og 'analogistisk' (jf. ovenfor, note 21) forbindes; mere end blotte indeksikale tegn er skriftlige kilders symbolske tegn tættere på de mentale processer som er det særlige kompetencefelt for nutidens forskere - disse sene efterkommere af de mesopotamiske præster... 
Andre forskere har derimod understreget processionerne som det centrale i akitufesten, det der betød noget for store befolkningsgrupper. Således Julye Midbead: "From indirect references, we know that akitu celebrations were joyous and merry. (...) Food and drink were in abundant supply. (...) People came from far and wide, lining the streets to catch a glimpse of the glorious statues of Marduk and the other gods as they paraded the streets of Babylon". ${ }^{43}$ Forskellen mellem de præstelige perspektiver og lægfolkets bestod ikke kun i forskellen imellem symbolske og indeksikale meddelelser - og dermed imellem det præcise og det upræcise, den komplekse og det enkle, det flertydige og det entydige, det abstrakte og det konkrete, det lette og det tunge - men formentlig også imellem det dramatisk-seriøse og det afslappetlystige. Meget muligt at akitu-festen genskabte verden, bekæmpede kaosmagterne, genoprettede den kosmiske orden og indsatte Marduk og hans jordiske konge i deres retmæssige positioner øverst i deres himmelske og jordiske hierarkier. Disse alvorlige temaer er formentlig i tilskuernes bevidsthed blevet overdøvet af fascinationen af gudestatuerne og forventningen om et mægtigt spise- og drikkegilde. Tre dage var tilmed offentlige fridage: d. 4., den 8. og den 11 (Toorn 1991, 334). Processionsdage var afbrydelse af arbejde og rutine, afslapning, hvile og glæde.

\section{Ingen dejlige dage i Jerusalem? Processioner med arken i Det Gamle Testamente}

Formentlig kan der tales om grundformer for hierofore processioner. I det foregående har jeg forstået hiero- og teofore processioner som gentagne begivenheder hvor en hellig genstand er blevet taget ud af sit tempel og ført rundt udenfor for til sidst igen at blive installeret i templet. En variant heraf vil være det tilfælde hvor processionens formål er første gang at installere guddommen permanent på et blivende sted. Man kan, med et bekvemt begrebspar, ${ }^{44}$ skelne imellem 'getting in' og 'staying in'. Type 1, 'getting in', etablerer en ny og i sagens natur ideel orden. Type 2, 'staying in', bekræfter denne ideelle orden, der ikke længere er ny, men tendentielt uforanderlig og 'evig' (fordi den er ideel). Man kan så i princippet forestille sig en yderligere type 3, 'leaving': En guddom kan vælge at forlade sin bolig, fx hvis omstændighederne ved stedet eller omgivelserne gør det u-attraktivt eller umuligt for guddommen at forblive der (ved forurening af boligen, ved den lokale eller nationale befolknings negligering af den ethos den pågældende guddom insisterer på). ${ }^{45}$ Denne sondring er relevant for at forstå en diskussion om processioner i den gammeltestamentlige forskning.

43 Midbead 2004, 5. jf. 96. 170-171; jf. van der Toorn 1991, 336. - Midbeads analyse af akitu-festen er også den mest religionsvidenskabeligt informerede; jf. referencen til Durkheim og fest-effervescens (s. 10-11).

44 Lånt fra den amerikanske NT-forsker E.P. Sanders (1977, 16-17).

45 Tidlige eksempler på at guddomme forlader deres jordiske bolig, er de sumeriske digt 'Klage over ødelæggelsen af Ur' og 'Klage over ødelæggelsen af Sumer og Ur' (i Pritchard 1969, 455-463. 611619), med kun rudimentære angivelse af årsagerne til hvorfor guderne forlod byen (nyere oversættelser på The Electronic Text Corpus of Sumerian Literature). Et tekstligt rodet, men alligevel markant 
I GT har processioner nemlig en problematisk status. På den ene side fortælles der flere gange, og på fremhævet måde, om processioner som en del af Jahve-dyrkelsen, så man let kan få det indtryk at processioner har været almindelige, yndede og uproblematisk legitime. Men på den anden side er der ingen beretninger om eller regler for regelmæssige, kalenderbestemte processioner i GT, i modsætning til offer-rutiner, som er detaljeret reguleret i de præsteskriftlige dele af Pentateuken. I GT-forskningen har det derfor været et diskussionspunkt om der overhovedet har været regelmæssige processioner som del af Jahve-dyrkelsen eller ej - primært hvad angår Jahvedyrkelsen i kongetiden, dvs. i århundrederne før det babyloniske eksil (587 f.Kr.). Fx antog GT-forskningen i første halvdel af det 20. årh. (ikke mindst den 'skandinaviske skole ${ }^{46}$ ) at Jahvedyrkelsen i Jerusalem i kongetiden uden tvivl havde omfattet processioner. ${ }^{47}$ Ved en årlig nytårsfest om efteråret, dvs. ved overgangen fra tørke- til regnsæson, ${ }^{48}$ skulle overgangen fra det gamle til det nye år være fejret med en procession, hvis centrum var arken, den transportable kasse, der som en hellig genstand skulle have markeret Jahves nærvær. ${ }^{49} \mathrm{Ud}$ over årets vending tematiserede festen Jahves kamp med kaosmagterne, hans genskabelse af verden og akklamation af Jahve som konge; deraf også betegnelsen 'tronbestigelsesfest'. Den svenske forsker Ivan Engnell foreslog desuden at festen havde indeholdt en temporær afsættelse af kongen, fulgt af hans genindsættelse.

At der har været en sådan årlig fest, virker rimeligt, selv om forskningens flertal har afvist at den indbefattede en ritualiseret genskabelse af en kaos-kamp med genskabelse af verden og en rituel afsættelse af kongen (jf. van der Toorn 1991, 340-344). Skepsis om hvorvidt en sådan nytårsfest har indeholdt en procession med arken, synes også udbredt i forskningen. Jeg vender tilbage til emnet nedenfor.

\subsection{Fortællinger om arken}

Under alle omstændigheder er processioner med arken fortalt eller på anden måde nævnt flere gange i GT. If. den præsteskriftlige udgave af Pentateukens beretning om

eksempel fra GT er Ezekiel-bogens beskrivelse af hvordan Jahves 'herlighed' (kabôd) forlod templet i Jerusalem som reaktion på afgudsdyrkelse og forurening (Ez 10-11).

46 Betegnelse for en vigtig retning inden for gammeltestamentlig forskning i perioden efter første verdenskrig og indtil engang i 1960'erne. Berømte navne er nordmanden Sigmund Mowinckel (18841965), svenskeren Ivan Engnell (1906-1964) og danskeren Aage Bentzen (1894-1953). Bogen Myter $i$ det gamle Testamente af Aarhus-forskerne Benedikt Otzen, Hans Gottlieb og Knud Jeppesen fra 1973 er en god sammenfatning.

47 Fx Engnell 1948, der dog ikke gør klart om det drejer sig om specielt hierofore processioner.

48 Altså i samme periode som de faktisk bevidnede fester i GT fra persisk-hellenistisk tid: 'forsoningsdagen' (bedre: 'tempelrenselsesdagen') og løvhyttefesten. Årlig tempelrenselse: Lev 16; 23,27-32; Num 29,7-11. Løvhyttefest: bl.a. Lev 23,34-35.39-43; Neh 8,14-16.

49 At den er kendt som 'pagtens ark', skyldes en deuteronomistisk fortolkning, if. hvilken arken var et skrin der indeholdt de to stentavler med de ti bud. Generelt til arken: Jeppesen 1998. I de tekster jeg her ser på, er dette ikke arkens funktion. 
israelitternes ophold i ørkenen og indvandring i Landet skal arken bæres af en udvalgt gruppe levitter. ${ }^{50} \mathrm{I}$ beretningerne om indvandringen i Landet i Josvabogen bæres arken af præster (Jos 3,3; 6,4; også i 1 Kong 8,3). Og i fortællingerne om arkens overførelse til Jerusalem i Samuelsbøgerne transporteres arken på en vogn, der er fremstillet til formålet (1 Sam 6,7-8; 2 Sam 6).

De sidstnævnte fortællinger er flettet sammen med beretningerne om Davids etablering af sit kongedømme med hovedstad i den erobrede by Jerusalem, dvs. som begivenheder der skal have fundet sted i forbindelse med etableringen af den første israelitiske stat; tidsrummet omsat til nutidig historisk kronologi vil så have været engang i det 10. årh. f. Kr. ${ }^{51}$ Fortællingerne beretter relativt udførligt om transporten af arken først fra det gamle tempel i Shilo til en slagmark, hvor en israelitisk hær kæmper uden held imod en filistæisk hær, der erobrer arken (1 Sam 5), derpå rundt imellem en række filistæiske byer, og siden dens transport til et foreløbigt opbevaringssted på israelitisk territorium (1 Sam 6) og endelig, med nyt besvær, til Jerusalem (2 Sam 6). Forløbet slutter med at arken placeres i Salomos tempel i Jerusalem (1 Kong 8,1-13). ${ }^{52}$ Beretningen, der næsten har karakter af en lille selvstændig rejseberetning, en odyssé på landjorden, er vævet sammen med de ligeledes legendariske beretninger om de to første konger i Jerusalem: om David, der etablerer Jerusalem som sin nye hovedstad og installerer sin guddom Jahve her, og om hans søn Salomo, der bygger templet der skal være arkens endegyldige opholdssted. Der er en stor mængde højdramatiske informationer om 'israelitisk religion' i denne beretning; her vil jeg nøjes med at kommentere nogle enkeltheder der har med procession at gøre.

Beretningen om arkens vej frem og tilbage igennem det israelitiske og det filistæiske landskab er en processionsberetning. Hvor arken er, er Jahve - så når arken bevæger sig, følger Jahve med. ${ }^{53}$ Men arken flytter sig ikke af sig selv; arkens flytninger hører til ritualernes domæne, dvs. til processionernes. ${ }^{54}$ Uanset om arken køres på en

50 Levitterne er i disse tekster en kategori af kultfunktionærer der i princippet tilhører lægfolket, men som arbejder under præstelige anvisninger; den mest prestigiøse grupper er kehatitterne, hvis privilegium det er at bære arken - med bærestænger for at undgå den direkte berøring, som kun præsterne kan foretage uden livsfare (Num 4).

51 Fortælleforløbet er som det meste i GT sammensat af delvis heterogene tekstdele, hhv. bearbejdet redaktionelt, og er basalt set legendarisk. Det er ikke en kilde til præcise historiske begivenheder i det 10. årh. f.Kr. (til arkæologien, jf. Berlejung 2016, 100-104; til David og Salomo generelt, jf. Finkelstein \& Silberman 2006); men det er en vigtig religionshistorisk kilde; jf. Lundager Jensen 1998, 118-123.

52 Hvormed arken forsvinder ud af historieberetningerne - en af grundene til forskernes skepsis mht. den historiske værdi af beretningerne om den. Påfaldende nok nævnes arken i Jer 3,16 i en passus der må være fra efter ødelæggelsen af Jerusalem i 587; 'I de dage (...) skal man ikke længere tale om Jahves pagts ark, ingen skal tænke på den, ingen skal huske den, ingen skal savne den, og der skal ikke laves nogen anden' - en performativt selvmodsigende profeti (i betragtning af dens skriftligg $\varnothing$ relse; samme type i Ex 17,14) som altså derfor endnu ikke er gået i opfyldelse.

531 Sam 4,3: 'Lad os hente Jahves pagts ark i Shilo, så han kan være med os og frelse os fra vores fjender'; v. 21: 'hun (...) sagde: Herligheden er forsvundet fra Israel. Med det mente hun, at Guds ark var taget som bytte'.

54 Næppe en helt triviel præcision; i profetens Ezekiels vision er 'Jahves herlighed' beskrevet som en tronvogn (Nielsen 1988, 38) der bevæger sig hastigt igennem luften båret af keruber (Ez 1). Arkens 
vogn eller bæres på skuldrene af levitter eller præster, er der under ingen omstændigheder tale om rent 'pragmatiske' handlinger; overalt foregår transporten kodificeret, efter regler for funktioner for bestemte grupper af mennesker, og under offentlig opmærksomhed. Arkens ankomst til israelitternes lejr sker under et mægtigt jubelråb (1 Sam 4,5). Arken sendes bort fra filistrenes byer (efter at den, eller rettere sagt Jahve, har spredt pest omkring sig) på en helt særlig vogn, trukket af to helt særlige trækdyr ("diegivende køer, som endnu ikke har båret åg": 1 Sam 6,7) og udstyret med kostbare guldfigurer. Da køerne trækker den til israelitisk territorium, modtages den med glæde $(6,13)$; vognen hugges i stykker, og køerne ofres som brændoffer (1 Sam 6,14). På dette sted dør (i en tekstlig vanskelig forståelig passage ${ }^{55}$ ) en større mængde israelitter, 'fordi de havde kigget på Jahves ark' (1 Sam 6,19), og den flyttes derpå ind i et særligt hus, der vogtes af en person der 'helliges' (givetvis: der får præstelige kvaliteter) til formålet. Samme procedure, men mere udførligt, berettes i 2 Sam 6, da arken skal flyttes op til Jerusalem, så Jahve kan få fast bopæl i Davids nye hovedstad. Her foregår transporten med stor militær eskorte; vognen ledes af den lokale præsts to sønner; og David og 'hele Israels hus' 'danser af alle kræfter' foran Jahve 'til sang og til spil af citere, harper, pauker, sistrer og cymbler' (v. 5). Flytningen afbrydes dramatisk, idet en af præstesønnerne, Uzza, ved en forseelse kommer til at berøre arken og falder død om på vejen, og arken placeres for en tid i et hus ved vejen. Da flytningen genoptages, 'ofres' der okser og fedekalve (v. 13). Vejen til det endelige hvilested, Salomos tempel, foregår endnu engang ved en procession der omfatter kongen selv, klan- og slægtsoverhoveder, præster og levitter, og hvis midtpunkt er arken og andre hellige genstande der ikke må berøres af lægfolk. Foran arken går Salomo selv og 'hele Israels menighed', og undervejs 'ofres' der utallige kør og får (v. 5). ${ }^{56}$

Uanset om sådanne processioner faktisk har fundet sted eller ej, er mønsteret klart. I centrum står tilstedeværelsen af en guddommelig magt, som normalt ikke er til stede i det daglige livs rum, altså i den normale ('profane') verden. Hvor arken er, er guddommen Jahve. Guddommelige væsener (i GT regnes der uproblematisk med væsener fra den guddommelige sfære: 'engle' osv.) og mennesker er to forskellige typer væsener, som råder over hvert sit rum: guddommen i sin himmel eller i sit tempel, og menneskene på jordens overflade under himmelen, og i den by og det landområde der omgiver templet. Grunden til adskillelsen er den ontologiske heterogenitet der består imellem de to. Guddomme og de genstande der formidler guddommens nærvær, slår ihjel eller sender ulykker, hvis mennesker komme for tæt på. Uzza falder død om på stedet da han uforvarende kommer til at røre ved arken. Forholdet er ikke

rejse foregår nede på jorden og meget langsomt (trukket af køer eller båret af mennesker). Der er ikke kun materialitet til forskel imellem ritual og myte, men også hastighed.

55 Måske har en ældre tekst haft en formulering der gjorde det klart at dødsfaldet skyldes mangel på præster: 'Men han (Jahve) slog 70 mænd, fordi ingen præster havde deltaget i fejringen, da de så Jahves ark' (til tekstkritisk analyse: McCarter Jr. 1980, 131).

56 De kommentarer, jeg har konsulteret, ser ikke noget problem i at der bliver 'ofret' langs processionsruten og diskuterer det derfor ikke (det er normalt, som også den danske oversættelse, at gengive det brugte verbum, zbh, med 'at ofre'). Jeg går ud fra at der ikke kan menes ofringer på et indviet alter etc., efter den form der beskrives fx i 1 Sam 2 og kodificeres i Lev 3, men mere alment slagtninger, givetvis i en eller anden ritualiseret form. 
moralsk, men materielt; Uzzas død er ikke en straf, men en ulykke. Når arken skal transporteres på en vogn eller med lange bærestænger på skuldrene af udvalgte mænd, er det if. denne forståelse ikke begrundet i hvad man kunne kalde kommunikativt-moralske grunde (som for at 'ære', at 'vise respekt'). Medieringen imellem ark og mennesker sker ikke for at betegne noget om guddommen, men et nødvendigt tiltag for at beskytte menneskene. Uzza gør sig heller ikke skyld i noget som efter nutidig-vestlig opfattelse kan betragtes som forkert efter moralske kriterier; han dør pga. en givetvis velment, men i situationen katastrofal tankeløs forglemmelse af et ontologisk vilkår. Kun præster kan røre ved hellige genstande (det er nærmest den funktionelle definition på en præst i GT). Uzza er nok søn af en præst; men han er ikke indviet ('helliget') som præst. Derfor er han et almindeligt ('profant') menneske, og derfor er han ubeskyttet imod den guddommelige magt.

\subsection{Regelmæssige hierofore processioner i GT?}

Processioner med arken som del af en årlig tilbagevendende nytårsfest er der altså ikke direkte tekstbelæg for i GT. Men der er formuleringer som kunne (og if. bl.a. den skandinaviske skole burde) forstås som henvisninger til en sådan praksis. Et af vigtige tekststeder er S1 24,7-10 hvor en bys 'ældgamle porte' opfordres til at løfte sig så 'ærens konge kan drage ind'. At 'ærens konge', dvs. Jahve, kunne 'drage ind' igennem porte, kunne efter mange forskeres mening dårligt forstås på anden måde end som en procession med en konkret genstand, der repræsenterede eller markerede Jahve selv; og denne genstand kunne dårligt være nogen anden end arken. ${ }^{57}$

Selv om teorien om en regelmæssig genkommende procession med arken - der blev antaget at være en hellig genstand der primært havde haft funktion i krigsførelse - fandt tilslutning også uden for den skandinaviske skole (Kraus 1978, 348), er den også blevet kritiseret. Argumenterne imod er dels det manglende eksplicitte kildebelæg, dels at de mest udførlige beretninger i GT om en procession med arken angår arkens installering på et helligsted, men derimod ikke om regelmæssige transporter fra og tilbage helligstedet, sådan som det ville være i en rundgang med arken som del af et genkommende processionsritual. ${ }^{58}$ Dette har dog ikke forhindret forskeren Herbert Niehr (1997) i at formulere en alternativ teori. Niehr accepterede at den transporterede genstand ikke kan have været arken. Samtidig antog han at der måtte have været hierofore processioner af en eller anden slags også i Jerusalem - i hvert fald i kongetiden, 'det første tempels periode', dvs. i århundrederne ned til den babyloniske ødelæggelse af Jerusalem og det babyloniske eksil (traditionelt: 587 f.Kr.), men formentlig også i den følgende persisk-hellenistiske periode ('det andet tempels periode') indtil hasmonæertiden (anden halvdel af 2. årh. f.Kr.). Niehr så ingen grund til at tvivle på at den transporterede genstand har været et regulært gudebillede af den lokale skytsguddom Jahve. De tekstlige belæg er her ca. de samme som for en procession med arken: at Jahvedyrkelsen i Jerusalem i det 1. årt. f.Kr. ikke i væsentlig grad

57 Tilsvarende steder: S1 47,6-8 (“Gud drager op under jubelråb ...”); S1 68,25 (“De ser dit festtog, Gud, min Guds og konges festtog i helligdommen”); S1 132 (v. 8: “Jahve, bryd op til dit hvilested ..."); jf. Mowinkel 1955, 65-66; Gottlieb 1966; 1973, 109-111.

58 Til den nyere forskningshistorie, jf. Niehr 1997, 86; udførligere fremstilling i Bauks 2010. 
har adskilt sig fra det normale nærorientalske mønster, at byer og templer generelt havde regelmæssige, teofore processioner, og at de steder i GT der blev fortolket som udslag af en procession med arken, lige så godt eller bedre kan fortolkes som en procession med et gudebillede. Når det i Sl 24 hedder at 'ærens konge kommer ind', skal det if. normal nærorientalsk sprogbrug tages bogstaveligt: Det er guddommen der kommer ind - og det vil have betydet guddommens statue. De kredse, der tilrettelagde de tekster, der nu udgør GT, fordømte ganske vist billeder af Jahve, og af guddomme i det hele taget, og ønskede at fortie at gudebilleder for de fleste havde været en uproblematisk del af dyrkelsen af Jahve i bl.a. Jerusalem. ${ }^{59}$

På linje med såvel den ældre forskning som Niehrs forslag vil jeg selv anse det for givet at Jahve-dyrkelsen i det meste af det første århundrede f.Kr. har indeholdt processioner med en materiel fremstilling af Jahves nærvær. Mindre afgørende er det om det har været i form af arken eller en egentlig gudestatue. De mere præcise forestillinger må givetvis have været forskellige. En statue vil uden tvivl, og helt på linje med normale nærorientalske forestillinger, vil være blevet forstået som en art beholder, der har indeholdt Jahve i en eller anden form - en 'fraktal' form, som en 'hypostase' eller en 'avatar' (for nu at anvende tre anakronistiske termer). Man kan dårligt forestille sig at arken er blevet forstået som en beholder for en guddom. Men funktionelt, i forhold til ritualet, er dette af underordnet betydning. Dels må statuers status have været mere end tvetydig: Hvis en guddom havde besluttet sig til at tage ophold i en statue-beholder, har det ikke forhindret at samme guddom også var til stede i andre statuer eller uden for statuer, og ved andre helligdomme end den som processionen havde med at gøre. Dels kunne nærvær af guder, som i øvrigt tænktes at opholde sig i statuer, også markeres på andre måder, bl.a. ved standarter, fx dem som den assyriske hær førte med sig i felten (Black \& Green 1995, 169; Ornan 2005, 91. 146. 170; Hrusha 2015, 73-74). Og den numinøse kraft der normalt er tilskrevet statuer, er i samme grad blevet tilskrevet den an-ikoniske genstand arken, som fortællingerne om arkprocessioner i GT viser.

Som sagt lyder et argument imod regelmæssige processioner af arken (eller en statue) som en del af Jahve-dyrkelsen at der i GT nok berettes om processioner med arken, men kun om installationen af arken i en helligdom (Berlejung 2003, 33) - altså om 'getting in', men ikke om 'staying in'. Men i så fald vil der være et paradoks, for når de gammeltestamentlige tekster beretter om processioner med arken, tager de processionsforløbet som sådan for noget selvfølgeligt. Der er ingen steder der antyder mangel på rituel kompetence hvad angår processioner. Alle beretninger fokuserer på den konkrete procession - ingen antyder den mindste tvivl om hvorvidt det er en god ide at afholde en procession eller nogen form for tøven med hensyn til hvordan en sådan skal gennemføres, hvem der skal deltage i den og i hvilken orden. Forfatterne af disse beretninger demonstrerer tydeligvis rituel kompetence. De må have været

59 Vigtig for Niehrs argumentation er at Jahve-templet i sig selv fundamentalt set er et hus for en statue (ibid., 91). Det er meget muligt at normal nærorientalsk religiøs praksis har været gængs i Jerusalem i persisk-hellenistisk tid, inkl. polyteisme, og at en 'Tora-prægning' af Jahve-dyrkelsen med billedforbud, monolatri, Jerusalem-centrisme osv. først er blevet praktisk virkelighed fra og med makkabæer-hasmonæer-perioden, jf. Niehr 1999; Kratz 2013, 278 / 2015, 199-200. 
fuldt fortrolige med processioner, uanset om dette kendskab skyldes erfaringer fra Jerusalem eller erfaringer med processioner andre steder og evt. for andre guddomme.

Er det plausibelt at Jerusalem har været det eneste sted i den Nære Orient uden regelmæssige processioner med en hellig genstand, statuer eller ikke-statue? Spørgsmålet er næsten synonymt med spørgsmålet: Var der ingen store fester i Jerusalem, hvor hellige genstande blev vist frem og transporteret rundt så alle kunne se dem, fester man kunne se frem til og glæde sig til, hvor folk kunne komme til byen og 'se Jahves ansigt' (på behørig afstand, givetvis, så der ikke indtraf uønskede ulykker)? Var Jerusalem virkelig byen uden en dejlig dag engang imellem?

\section{Processionsløs religion}

I GT kan man formentlig iagttage dannelsen af en anti-processions-religion. Når GT overhovedet udtaler sig om fremmede guder, er det typisk med hån, spot og latterliggørelse - som det ovennævnte sted i Esajas-bogen, hvor akitu-festens to hovedguddomme, Marduk og Nabu, reduceres til hule statuer, som kun svagt begavede mennesker kan tildele betydning: "Bel går i knæ, Nebo synker sammen, gudebillederne læsses på lastdyr og okser". Gudestatuer værdiløse affaldsprodukter og klamphuggerier; der er ikke noget inden i dem, og de skal have hjælp til al ting, selv til at bevæge sig. ${ }^{60}$ At Jahve-religionen ikke tolererer billeder af Jahve selv eller af andre guder, er det næst-vigtigste teologiske princip i Dekalogen, umiddelbart efter kravet om Jahve-monolatri: 'Du må ikke have andre guder end mig ... Du må ikke lave dig noget gudebillede i form af noget som helst ...' (Deut 5,7-8).

Hvad der gerne omtales som 'billed-forbudet' i GT, og som mere præcist er et forbud imod at fremstille gudestatuer, hører hjemme i en bestemt gammeltestamentlig teologi, den 'deuteronomistiske' ${ }^{61}$ Denne teologi skal som sagt ikke tages som en gengivelse af en faktisk udøvet religionsform blandt israelitter i det første årt. f.Kr.; det var et program for hvordan Jahve-religionen burde være og burde have været if. de kredse i hvilke disse tekster er forfattet. Men selv om 'billedforbuddet' er deuteronomistisk, er det mere eller mindre gennemført i GT som helhed. Der er nok antydninger af en anden tilstand jf. de nævnte spor efter regelmæssige processioner bl.a. i salmerne. Men der er ingen tekster bevaret der har vovet at tale deuteronomismen lodret imod. GT-forskningen har med gode grunde diskuteret rationalet i dette forbud og ofte fundet et svar i særlige træk ved guddommen Jahve: hans engagement $\mathrm{i}$ historiske begivenheder og hans mangel på entydighed, egenskaber som antages at være inkompatible med billeder (fx Nielsen 1998). En variant af denne forklaring har været

60 Polemikken imod gudebilleder i GT - religionskritikkens fødsel - har oftest karakter af latterliggørelse, jf. fx Ex 44,9-20; 45,20; Jer 10,3-5.8-9.15-15; Deut 4,28; Sl 115,4-8; jf. den apokryfe satire i Tilføjelserne til Daniels Bog: Daniel og Bel (dvs. Marduk).

61 'Deuteronomismen' er en teologi med særlig vægt på den etnisk-sociale konsistens internt blandt Jahve-dyrkere, en forankring i historiske overleveringer og med en klar markering af det religiøst og socialt inkompatible imellem denne og alle andre former for gudsdyrkelse. Til flerheden af teologier i GT, jf. Gudme et al. 2016. 
at at billeder var udtryk for en 'tingslig forståelse' der lagde op til 'magisk manipulation', mens en billedløs guddom var en 'person' der møder sine dyrkere som 'personer' (Kaiser 1998, 180).

Jeg selv vil her kort til slut foreslå en anden forklaring på rationalet bag forbuddet imod at dyrke Jahve i skikkelse af et billede. ${ }^{62}$ Den 'deuteronomistiske' Jahve-religion var en religionsform for en enklave, en 'overlevelses-enhed' i en omverden af kulturel og religiøs hegemoni. ${ }^{63}$ Det var en religionsform der ikke var bundet til en bestemt by eller et bestemt sted, sådan som dyrkelse af guddomme i store templer nødvendigvis måtte være, men som kunne udøves og leves hvor som helst. Den kunne altså praktiseres af diaspora-grupper lige så vel som af befolkningen i fx Jerusalem. Og den var funderet i skriftlig kommunikation, ikke i genstande.

Ingen (overlevelsesdygtig) religion uden regelmæssige forsamlinger (jf. Durkheim). En model for hvordan en billedløs forsamling kan have taget sig ud, findes i beskrivelsen af en oplæsning af Jahves (nedskrevne) tora, dvs. belæring, i Neh 8. ${ }^{64}$ Denne begivenhed, i Jerusalem, i persisk tid, er uden tvivl idealiseret - men det er også idealet der er relevant $\mathrm{i}$ denne sammenhæng, ${ }^{65}$ for her aftegnes de fundamentale træk ved regulære gudstjenester i jødedom, kristendom og islam. Hele befolkningen deltager, mænd, kvinder og større børn, under ledelse af den skriftkyndige Ezra, der er suppleret med en gruppe levitter der også har indsigt i skriften og i sagen. Man rejser sig ved præsentationen af skriften, man kaster sig til jorden, man svarer med et bekræftende 'amen'. Her er intet monumentalbyggeri, ingen altre, ingen ofringer under ledelse af præster, ${ }^{66}$ ingen residerende guddom, ingen regler om 'renhed' som forudsætning for deltagelse. Kort sagt: intet tempel. If. Neh. var der et tempel i Jerusalem, et tempel for Jahve med præster, alter og offerpraksis. Men i kap. 8 er templet helt irrelevant. Dette er en form for religion der kan klare sig uden et tempel. Formentlig er det en form for religion der tilmed hæmmes af et tempel.

Uden tempel ingen hiero- eller teofore processioner. Arkaiske religioners templer var bygget for guddomme der skulle vises frem i processioner. Den nye Jahve-religion var en religion uden processioner. Men den var ikke en religion uden fest. Oplæsningen af belæringen if. Neh 8 er en alvorlig sag, og tilhørerne brister i gråd over deres mangel på viden om hvad Jahve-religionen går ud på. Ezra sørger for at standse uroen, og han opfordrer til at deltagerne afholder et stort måltid: "spis fede retter og

62 En mere udfoldet argumentation kan ses i Lundager Jensen 2017.

63 Til begrebet 'enklave' som relevant beskrivelse af den deuteronomistiske Jahve-religion, jf. Douglas 1993, 43-62.

64 Udførligt herom i: Søgaard Christensen 2016.

65 Et solidt durkheimiansk princip: Det der konstituerer et samfund, er kollektive idealer (Durkheim 1994 [1912], 600-606 / 1995, 422-425); det der adskiller samfund eller kulturer, er derfor ikke hvordan de faktisk er, men hvordan de gerne vil være og gerne fremstå for sig selv og for andre.

66 Ezra, der oplæser skriften, er ganske vist også præst (kohen), men han er fremfor alt skriftkyndig (soper), og det er alene i den egenskab han praktiserer her. 
drik sød vin". Levitterne supplerer: "Vær stille, for denne dag er hellig! Vær ikke bedrøvede!". Også i Jerusalem forstår man at religion, fridag og alkohol hører sammen; men hvor den indeksikale statue var, er den symbolske skriftrulle kommet. ${ }^{67}$

En ting er at få nye religiøse principper på plads - noget andet at immunisere sig selv og sin gruppe imod alternativer. Der boede grupper af judæere (sådan har de forstået sig: Kratz 2014, 187 / 2015, 137. 148) i Mesopotamien, i Egypten og overalt i den Nære Orient og det østlige Middelhavsområde. Det har været svært for residerende judæere at modstå fristelsen til at blive revet med i den generelle effervescens på de store fest- og fridage. Det har ikke været let at blive hjemme og lade som ingenting, når alle andre har kæmpet sig frem til en god plads til at se processionen. I denne sammenhæng giver latterliggørelsen af gudebilleder mening. Statuerne er der, de kan ikke ignoreres. Men man kan lære at gennemskue dem. Man kan øve sig selv og hinanden i at forstå at statuer ikke er guder, selv om alle andre mennesker omkring én agerer som om de er det, selv om alle andre mennesker er tumper som er lige som tomme som billederne selv. ${ }^{68}$ Måske kunne man endda stille sig op og se med når statuerne defilerede forbi? Man har kunnet forbyde Jahve-tilhængere at fremstille billeder af Jahve, og man har kunnet latterliggøre andre der fremstillede billeder af sig selv. Det har formentlig været umuligt at forbyde jøder i diasporaen (hhv. 'seriøse' jøder i Jerusalem) at overvære processioner. Men man har kunnet forsøge at indbygge en modstandskraft imod processioner. Dette program har været succesrigt. I de protestantiske retninger af kristendommen er immuneffekten endnu ikke taget helt af.

\title{
LITTERATUR
}

\author{
Assmann, Jan \\ 1991 "Das ägyptische Prozessionsfest", in: Das Fest und das Heilige. Religiose Kontrapunkte zur \\ Alltagswelt, Gütersloh: Gütersloher Verlagshaus Gerd Mohn, 105-122. \\ 1996 Ägypten. Eine Sinnsgeschichte, Darmstadt: Wissenschaftliche Buchgesellschaft. \\ 2008 Of God and Gods. Egypt, Israel, and the Rise of Monotheism, Madison: The University of Wisconsin \\ Press. \\ Bartlett, Robert \\ 2013 Why can the Dead do Such Great Things? Saints and Worshippers from the Martyrs to the Reformation, \\ Princeton, NJ: Princeton University Press. \\ Bauks, Michaela \\ 2010 “Prozession", in: WibiLex (Das wissenschaftliche Bibellexikon im Internet). \\ http://www.bibelwissenschaft.de/wibilex/ \\ Bellah, Robert N \\ 1964 "Religious Evolution", American Sociological Review 29 (3), 358-374. \\ https://doi.org/10.2307/2091480 \\ 2011 Religion in Human Evolution. From the Paleolithic to the Axial Age, Cambridge, MA: The Belknap \\ Press of Harvard University Press. https://doi.org/10.4159/harvard.9780674063099
}

67 Til den senere jødiske skik med at omgås med toraruller i synagoger som om de var gudebilleder, jf. van der Toorn 1997, 242-243.

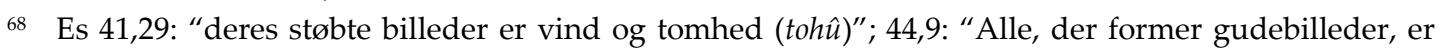
tomme $($ toh $\hat{u}) "$. 
Berger, Ulrich

2008 Jesaja 40-48, Freiburg: Herder.

Berlejung, Angelika

2003 "Heilige Zeiten. Eine Forschungsbericht", Jahrbuch für Biblische Theologie 18, 3-61.

2016 "Geschichte und Religionsgeschichte des antiken Israel“, in: Jan Chr. Gertz, ed. Grundinformation Altes Testament, 5. ed., Göttingen: Vandenhoeck \& Ruprecht, 59-192.

Bidmead, Julye

2004 The Akitu Festival. Religious Continuity and Royal Legitimation in Mesopotamia, Piscataway, NJ: Gorgias Press.

Black, Jeremy \& Anthony Green

1995 Gods, Demons and Symbols of Ancient Mesopotamia. An Illustrated Dictionary, Austin: University of Texas Press.

Canney, M.A

1938 "Boats and Ships in Processions", Folklore 49 (2), 132-147. https://doi.org/10.1080/0015587X.1938.9718740

Cohen, Mark E.

1993 The Cultic Calendars of the Ancient Near East, Bethesda, Maryland: CDL Press.

Darnell, John

2010 “Opet festival”, UCLA Encyclopedia of Egyptology. https://escholarship.org/uc/nelc_uee

Descola, Philippe

2010 "Un monde entrevêtré", in: idem, ed., La fabrique des images. Visions du monde et formes de la représentation, Paris: Musée du quai Branly, 166-183.

Douglas, Mary

1993 In the Wilderness. The Doctrine of Defilement in the Book of Numbers, Sheffield: Sheffield Academic Press.

Durkheim, Emile

1994 Les formes élémentaires de la vie religieuse. Le systemè totémique en Australie, Paris: Quadrige/PUF (1912).

1995 The elementary forms of religious life, transl. Karen E. Fields, New York: Free Press.

Engnell, Ivan

1948 "Gudstjänst, kult”, Ivan Engnell \& Anton Fridrichsen, eds., Svensk Bibelskt Uppslagsverk, Gävle: Skolförlaget, 753-756.

Finkelstein, Israel \& Neil Asher Silberman

2006 David and Solomon: in search of the Bible's sacred kings and the roots of the Western tradition, New York: Free Press.

Foucault, Michel

1983 “Des Espace Autres: Hétérotopies"; http://desteceres.com/heterotopias.pdf

Geller, M.J.

1997 "The Last Wedge“, Zeitschrift für Assyriologie 87, 43-95. https://doi.org/10.1515/zava.1997.87.1.43

Gerstenberger, Erhard S.

2001 Theologien im Alten Testament, Stuttgart: Kohlhammer.

2002 Theologies in the Old Testament, transl. John Bowden, London: T \& T Clark.

Gottlieb, Hans

1966 “Optog”, in: Eduard Nielsen \& Bent Noack, eds., Gads danske Bibelleksikon, København: Gad, 399-400.

1973 “Myter i salmerne”, in: Benedikt Otzen, Hans Gottlieb \& Knud Jeppesen, Myter i Det gamle Testamente, København: Gad, 85-124.

Gudme, Anne Katrine de Hemmer, Søren Holst, Jesper Høgenhaven \& Frederik Poulsen

2017 Fire indgange til gammeltestamentlig teologi, Afdeling for Bibelsk Eksegese, Det Teologske Fakultet, København. 
Hays, Christopher B.

2014 Hidden Riches. A Sourcebook for the Comparative Study of the Hebrew Bible and Ancient Near East, Louisville Kentucky: Westminster John Knox Press.

Hornung, Erik

1995 Echnaton. Die Religion des Lichtes, Düsseldorf: Artemis \& Winkler.

Hrusha, Ivan

2015 Ancient Mesopotamian Religion. A Descriptive Introduction, Münster: Ugarit-Verlag.

Hutter, Manfred

1996 Religionen in der Umwelt des Alten Testaments 1. Babylonier, Syrer, Perser, Stuttgart: Kohlhammer.

Jeppesen, Knud

1998 "Ark", in: Gads Bibel Leksikon, København: Gad, 44-45.

Kemp, Barry J.

1989 Ancient Egypt. Anatomy of a Civilization, London: Routledge.

Koch, Ulla, \& Aage Westenholz

2015 Gilgamesh. Enuma elish. Guder og mennesker i oldtidens Babylon, 2. ed., Højbjerg: Univers.

Kratz, Rainhard Gregor

2013 Historisches und biblisches Israel, Tübingen: Mohr Siebeck.

2015 Historical \& Biblical Israel. The History, Tradition, and Archives of Israel and Judah, transl. Paul Michael Kurtz, Oxford: Oxford University Press. https://doi.org/10.1093/acprof:oso/9780198728771.001.0001

Kraus, Hans-Joachim

1978 Psalmen 1-59, 5. ed., Neukirchen: Neukirchener Verlag.

Lundager Jensen, Hans J.

1998 Gammeltestamentlig religion. En indføring, Frederiksberg: Anis.

2000 Den fortærende ild. Strukturelle analyser af narrative og rituelle tekster i Det Gamle Testamente, Aarhus: Aarhus Universitetsforlag.

2003 "Roy Rappaport: Ritual and Religion in the Making of Humanity", Religionsvidenskabeligt Tidsskrift 43, 71-77.

2016a “Ontologier i Det Gamle Testamente: analogisme og animisme (Gen 1 og 2-3)”, Collegium Biblicum Årsskrift 20, 1-19.

2016b "Land, by, netværk: Tre religionstyper i Bibelen", Kritisk Forum for Praktisk Teologi, 143, 3-19.

2017 "Aniconic propaganda in the Hebrew Bible, or: the possible birth of religious seriousness" Religion, 17.3.2017. http://doi.org/10.1080/0048721X.2017.1295827

McCarter Jr., P. Kyle

19801 Samuel, New York: Doubleday.

Mowinkel, Sigmund

1955 Det Gamle Testamente IV. Skrifterne. 1. del, Oslo: Aschehoug.

Niehr, Herbert

1997 "In Search of Yahweh's Cult Statue in the First Temple", in: Karel van der Toorn, ed., The Image and the Book. Iconic Cults, Aniconism, and the Rise of Book Religion in Israel and the Ancient Near East, Leuven: Peeters, 73-95.

1999 "Religio-Historical Aspects of the 'Early Post-Exilic' Period", in: Bob Becking \& Marjo C.A. Korpel, eds., The Crisis of Israelite Religion. Transformations of Religious Tradition in Exilic and PostExilic Times, Leiden: Brill, 228-244.

Nielsen, Kirsten

1988 Ezekiels Bog fortolket, København: Det danske Bibelselskab.

1998 "Billedforbud", in: Geert Hallbäck \& Hans J. Lundager Jensen, eds., Gads Bibel Leksikon, København: Gad, 96.

North, Christopher R.

1964 The Second Isaiah, Oxford: Clarendon Press. 
“Opetfest”

1982 "Opetfest", in: Wolfgang Helck, Eberhard Otto \& Wolfhart Westendorf, eds., Lexikon der Ägyptologie 4, 574-579.

Ornan, Tallay

2005 The Triumf of the Symbol. Pictoral Representations of Deities in Mesopotamia and the Biblical Image Ban, Göttingen: Vandenhoeck \& Ruprecht.

Otzen, Benedikt, Hans Gottlieb \& Knud Jeppesen

1993 Myter i Det gamle Testamente, København: Gad.

Overmyer, Daniel L.

1997 "Convergence: Chinese Gods and Christian Saints", Ching Feng, 215-232.

Pongratz-Leisten, Beate

1994 Ina šulmi ìrub. Die kulttopographische und ideologische Programmatik der akitu-Prozession in Babylonien und Assyrien im 1. Jahrtausend v. Chr., Baghdader Forschungen 16, Mainz: Phillip von Zabern.

Price, Simon

1999 Religions of the Ancient Greeks, Cambridge: Cambridge University Press. https://doi.org/10.1017/cbo9780511814488

Pritchard, James B., ed.

1969 Ancient Near Eastern texts Relating to the Old Testament. 3. ed. with suppl., Princeton, NJ: Princeton University Press.

Rappaport, Roy A.

1979 "The Obvious Aspects of Ritual”, in: Roy A. Rappaport, Ecology, Meaning. and Ritual, Berkeley, California: North Atlantic Books, 173-221.

1999 Ritual and Religion in the Making of Humanity, Cambridge: Cambridge University Press. https://doi.org/10.1017/CBO9780511814686

Ravn, O.E.

1934 Babylonske og assyriske kongers historiske indskrifter, København: Selskabet til historiske kildeskrifters oversættelse.

Sanders, E.P.

1977 Paul and Palestinian Judaism: A comparison of patterns of religion, London: SCM Press.

Sauneron, Serge

1998 Les prêtres de l'ancienne Égypte, 2. ed., Paris: Seuil.

Schaudig, Hanspeter

2008 “'Bel Bows. Nabu stoops!' The Prophecy of Isaiah XLVI 1-2 as Reflection of Babylonian 'Processional Omens'”, Vetus Testamentum, 557-572. https://doi.org/10.1163/156853308X325281

Schott, Siegfried

1952 Das schöne Fest vom Wüstentale. Festbräuche einer Totenstadt, Weisbaden: Franz Steiner.

Sloterdijk, Peter

2009 Du musst dein Leben ändern. Über anthropotechnik, Frankfurt am Main: Suhrkamp.

2013 You Must Change Your Life. On Anthropotechnics, transl. Wieland Hoban, Cambridge: Wieland Hoban, Polity.

Smith, Morton

1952 "The Common Theology of the Ancient Near East", Journal of Biblical Literature 71 (3), 135-147. https://doi.org/10.2307/3261800

Sommer, Benjamin

2000 "The Babylonian Akitu Festival: Rectifying the King or Renewing the Cosmos?", Journal of the Ancient Near Eastern Society 27, 81-95.

Stadler, Martin

2008 “Procession”, UCLA Encyclopedia of Egyptology. https://escholarship.org/uc/item/679146w5 
Søgaard Christensen, Line

2016 Instructing the Israelites: Axiality, teaching and rituals in the Hebrew Bible, Graduate School of Arts, Theology, Aarhus University, Aarhus.

Trigger, Bruce G.

2003 Understanding Early Civilizations: A Comparative Study, Cambridge: Cambridge University Press. https://doi.org/10.1017/CBO9780511840630

Van De Mieroop, Marc

1999 The ancient Mesopotamian city, Oxford: Oxford University Press.

van der Toorn, Karel

1991 "The Babylonian New Year Festival: New Insights from the Cuneiform Texts and Their Bearing on Old Testament Study", in: J.A. Emerton, ed., Congress Volume. Leuven 1989 (Supplements to Vetus Testamentum 43), Leiden: Brill, 331-244. https://doi.org/10.1163/9789004275669_021

1997 "The Iconic Book. Analogies Between the Babylonian Cult of Images and the Veneration of the Torah", in: Karel van der Toorn, ed., The Image and the Book. Iconic Cults, Aniconism, and the Rise of Book Religion in Israel and the Ancient Near East, Leuven: Peeters, 229-248.

Zaidman, Louise Bruit \& Pauline Schmitt Pantel

1992 Religion in the Ancient Greek City, transl. Paul Cartledge, Cambridge: Cambridge University Press. https://doi.org/10.1017/CBO9780511814457

Zgoll, Annette

2006 "Köningslauf und Götterrat: Struktur und Deutung des babylonischen Neujahrsfestes", in: Erhard Blum \& Rüdiger Lux, eds., Festtraditionen in Israel und im Alten Orient, Gütersloh: Gütersloher Verlagshaus, 11-80.

Hans J. Lundager Jensen, prof., dr. theol., Afdeling for Religionsvidenskab, Aarhus Universitet hj@cas.au.dk 